\title{
Prevalence and co-infection of Toxoplasma gondii and Neospora caninum in Apodemus sylvaticus in an area relatively free of cats
}

\author{
D. THOMASSON ${ }^{1}$, E. A. WRIGHT ${ }^{1}$, J. M. HUGHES ${ }^{1}$, N. S. DODD ${ }^{1}$, A. P. COX ${ }^{2}$, \\ K. BOYCE ${ }^{1}$, O. GERWASH ${ }^{1}$, M. ABUSHAHMA ${ }^{1}$, Z.-R. LUN ${ }^{3}$, R. G. MURPHY ${ }^{1}$, \\ M. T. ROGAN ${ }^{1}$ and G. HIDE ${ }^{1} *$ \\ ${ }^{1}$ Centre for Parasitology and Disease Research, School of Environment and Life Sciences, University of Salford, Salford \\ M5 4WT, UK \\ ${ }^{2}$ London School of Hygiene and Tropical Medicine, Keppel Street, London WC1E 7H, UK \\ ${ }^{3}$ Center for Parasitic Organisms, State Key Laboratory of Biocontrol, School of Life Sciences and Key Laboratory of \\ Tropical Disease and Control of the Ministry of Education, Zhongshan Medical College, Sun Yat-Sen University, \\ Guangzhou 510275, P.R. China
}

(Received 23 February 2011; revised 19 April and 7 May 2011; accepted 9 May 2011; first published online 15 fuly 2011)

\section{SUMMARY}

The protozoan parasite Toxoplasma gondii is prevalent worldwide and can infect a remarkably wide range of hosts despite felids being the only definitive host. As cats play a major role in transmission to secondary mammalian hosts, the interaction between cats and these hosts should be a major factor determining final prevalence in the secondary host. This study investigates the prevalence of $T$. gondii in a natural population of Apodemus sylvaticus collected from an area with low cat density $\left(<2 \cdot 5\right.$ cats $\left./ \mathrm{km}^{2}\right)$. A surprisingly high prevalence of $40 \cdot 78 \%(95 \%$ CI: $34 \cdot 07 \%-47 \cdot 79 \%)$ was observed despite this. A comparable level of prevalence was observed in a previously published study using the same approaches where a prevalence of $59 \%(95 \%$ CI: $50 \cdot 13 \%-67 \cdot 87 \%)$ was observed in a natural population of Mus domesticus from an area with high cat density $\left(>500\right.$ cats $\left./ \mathrm{km}^{2}\right)$. Detection of infected foetuses from pregnant dams in both populations suggests that congenital transmission may enable persistence of infection in the absence of cats. The prevalences of the related parasite, Neospora caninum were found to be low in both populations (A. sylvaticus: $3 \cdot 39 \%$ (95\% CI: $0 \cdot 12 \%-6 \cdot 66 \%$ ); M. domesticus: $3 \cdot 08 \%$ $(95 \%$ CI: $0 \cdot 11 \%-6 \cdot 05 \%))$. These results suggest that cat density may have a lower than expected effect on final prevalence in these ecosystems.

Key words: Toxoplasma gondii, Neospora caninum, PCR, Apodemus sylvaticus, Mus domesticus, vertical transmission.

\section{INTRODUCTION}

The protozoan parasite Toxoplasma gondii is prevalent worldwide, infects a wide range of hosts and is generally found in high prevalence (Tenter et al. 2000). Amongst the Apicomplexa it is distinguished for its ability to readily infect almost any mammal, as well as birds, despite felids being the only definitive host (Dubey et al. 1970; Dubey, 2009a,b). Rodents, and in particular mice, are considered to be an important intermediate host as they are a potential prey species for cats (Tenter et al. 2000). They may play an important role in the completion of the life cycle of $T$. gondii by providing a source of infected meat for the cat which leads to subsequent infection of more secondary hosts. Despite this apparently important role, a number of serological studies have shown that $T$. gondii has a relatively low prevalence in

* Corresponding author: Centre for Parasitology and Disease, School of Environment and Life Sciences, University of Salford, Salford M5 4WT, UK. Tel: $00441612953371 . \quad$ Fax: $00441612955015 . \quad$ E-mail: g.hide@salford.ac.uk mice (Franti et al. 1976; Jackson et al. 1986; Webster, 1994; Dubey et al. 1995; Smith and Frenkel, 1995) although some PCR-based studies of T.gondii in Mus domesticus, and other species of mice, have shown higher prevalences (Marshall et al. 2004; Zhang et al. 2004). Few studies have been conducted to date on the woodmouse, Apodemus sylvaticus. Prevalences of T. gondii of $14 \cdot 3 \%$ have been reported, using PCR, in one study (Kijlstra et al. 2008) and seroprevalences of $1 \cdot 49 \%$ and $7 \cdot 4 \%$ were found in Apodemus agrarius in Korea (Jeon and Yong, 2000) and the Czech Republic (Hejlicek and Literak, 1998). The assumption is that these natural populations of wild mammals are infected through interaction with cats.

Infected cats release large quantities of oocysts $\left(10^{7}-10^{8}\right.$ per cat $)$ that are environmentally persistent and previous reports suggested that younger cats shed more frequently than older or previously exposed cats (Dubey, 1995). However, recent large-scale studies (Schares et al. 2008; Herrmann et al. 2010) have demonstrated frequent shedding of oocysts by older cats. It is estimated that only a small proportion $(1-2 \%)$ of domestic cats may be shedding oocysts at 
any one time (Dubey and Beattie, 1988; Dubey and Jones, 2008) but this could be as low as $0 \cdot 25 \%$ (Herrmann et al. 2010). Overall, these data imply that a higher prevalence of $T$. gondii would be found in intermediate hosts in an area with large cat populations.

$T$. gondii is transmitted via 3 routes; the ingestion of oocysts from the environment, ingestion of tissue cysts by the intermediate host, and congenitally through transplacental transmission from mother to foetus. The contribution of each of these routes to the overall prevalence of the $T$. gondii is currently a subject of debate (Hide et al. 2007, 2009; Innes et al. 2009). There is considerable evidence now that the parasite might frequently engage in transmission cycles that bypass cats (Su et al. 2003; Dubey et al. 2005) but the relative importance of different transmission routes is still unclear. A number of studies have suggested that vertical transmission may be an important transmission route in natural populations of mammals such as sheep (Duncanson et al. 2001; Williams et al. 2005; Morley et al. 2005, 2008) and perhaps humans (Hide et al. 2007, 2009). Although congenital transmission of $T$. gondii has been studied in mice under laboratory conditions, few studies have looked at this phenomenon in naturally infected wild populations.

In a laboratory study, Owen and Trees (1998) looked at chronically infected house mice (Mus musculus) and wood mice (A. sylvaticus) using PCR. Vertical transmission was demonstrated in $82.7 \%$ of all pups and in $95 \%$ of all litters of $A$. sylvaticus showing that it is extremely efficient in this species and probably endures for the life of the breeding female. Another earlier study by Beverley (1959) looked at congenital transmission of toxoplasmosis through successive generations of mice. Beverley (1959) reported that 23 of the infected litters were born of mothers, themselves congenitally infected, and in one instance a congenitally infected mother produced congenitally infected offspring even in her fourth litter. In a field study, PCR testing of $T$. gondii in foetuses, collected from a natural population of wild $M$. domesticus, demonstrated that congenital transmission was occurring in $75 \%$ of mice and rose to $100 \%$ when only PCR positive mothers were considered (Marshall et al. 2004). However, most studies conducted using serological techniques have suggested lower rates of congenital transmission in rodents (Dubey et al. 1995) although this may be due to sensitivity of the serological tests which often show that congenitally infected mice can test seronegative while harbouring parasites (Beverley, 1959; Jacobs, 1964; Dubey et al. 1997; Owen and Trees, 1998; Araujo et al. 2010).

The related parasite, Neospora caninum, undergoes frequent vertical transmission (Cole et al. 1995; Williams et al. 2009) but little is known about its prevalence in natural populations of rodents nor the degree of co-infection with $T$. gondii. Studies using PCR detection of Neospora and Toxoplasma have demonstrated evidence of co-infection in sheep, mice, rats (Hughes et al. 2006) and rabbits (Hughes et al. 2008) but no significant association between the two parasites.

In this paper we report the results of a study that investigates the prevalence of $T$. gondii and $N$. caninum in a wild population of $A$. sylvaticus. At the location of the sampling site there are few cats present locally - less than $2 \cdot 5$ cats per $\mathrm{km}^{2}$ (based on the data of Hughes et al. 2008). This offers the opportunity to compare directly, using an identical methodology, the prevalence of $T$. gondii in rodents in an area relatively free of cats with a previously published study on an area where there were more than 500 cats per $\mathrm{km}^{2}$ (based on the data of Murphy et al. 2008). The objectives of this study are to investigate the prevalence and co-infection of $T$. gondii and $N$. caninum in A. sylvaticus and to compare the prevalence of $T$. gondii in rodents in areas with high and low cat densities.

\section{MATERIALS AND METHODS}

The woodmice (A. sylvaticus) were sampled, using Longworth Traps, from the surrounding area of Malham Tarn Field Centre, North Yorkshire. Mice weighing less than $14 \mathrm{~g}$ were considered juveniles (Higgs and Nowell, 2000). They were euthanased, measured, weighed, sexed and the brains dissected out, using sterile technique, and transferred into sterile tubes containing $400 \mu \mathrm{l}$ of lysis buffer $(100 \mathrm{mM}$ sodium chloride, $25 \mathrm{~mm}$ EDTA, 0.5\% SDS, $20 \mathrm{~mm}$ Tris $\mathrm{pH} 8 \cdot 0$ ) and stored at $-20^{\circ} \mathrm{C}$. Instruments were sterilized between dissections and crosscontamination of samples was prevented at all stages by the use of disposable sterile equipment (e.g. tubes, tips), careful handling, labelling and sample processing during DNA extraction.

DNA was extracted using a phenol/chloroform procedure as previously described ('Terry et al. 2001). Uninfected and T. gondii (RH Strain)-infected mouse tissue (J.E. Smith, University of Leeds) were used as DNA-processing controls. The extracted DNA was tested to ensure viability for PCR using generic primers to mammalian $\alpha$-tubulin as previously described (Duncanson et al. 2001; Morley et al. 2005). The presence of $T$. gondii was detected using PCR amplification of the Surface Antigen Gene 1 (SAG1) gene and resolved by gel electrophoresis as previously described (Williams et al. 2005). Precautions were taken to avoid contamination during nested PCR reactions as follows: negative controls (sterile distilled water) were included as the first and last sample of any set of PCR reactions. Positive controls used were DNA extracted from $T$. gondii reference strains (typically $\mathrm{RH}$ ) and a cloned 
Table 1. Summary of the SAG 1 PCR detection of Toxoplasma gondii and Neospora caninum in A. sylvaticus and M. domesticus

(Data from Mus domesticus were obtained from previously published studies (Marshall et al. 2004; Murphy et al. 2008.)

\begin{tabular}{|c|c|c|c|c|c|c|}
\hline & \multicolumn{3}{|c|}{ Toxoplasma gondii } & \multicolumn{3}{|c|}{ Neospora caninum } \\
\hline & $\begin{array}{l}\text { PCR } \\
\text { positive }\end{array}$ & $\begin{array}{l}\text { Total } \\
\text { tested }\end{array}$ & $\begin{array}{c}\text { Prevalence\% } \\
(95 \% \text { CI })\end{array}$ & $\begin{array}{l}\text { PCR } \\
\text { positive }\end{array}$ & $\begin{array}{l}\text { Total } \\
\text { tested }\end{array}$ & $\begin{array}{c}\text { Prevalence\% } \\
(95 \% \text { CI })\end{array}$ \\
\hline $\begin{array}{l}\text { Apodemus } \\
\text { sylvaticus }\end{array}$ & 84 & 206 & $\begin{array}{l}40 \cdot 78 \\
(34 \cdot 1-47 \cdot 8)\end{array}$ & 4 & 118 & $\begin{array}{l}3 \cdot 39 \\
(0 \cdot 12-6 \cdot 66)\end{array}$ \\
\hline Mus domesticus & 118 & 200 & $\begin{array}{l}59 \\
(50 \cdot 1-67 \cdot 9)\end{array}$ & 4 & 130 & $\begin{array}{l}3 \cdot 08 \\
(0 \cdot 11-6 \cdot 05)\end{array}$ \\
\hline
\end{tabular}

SAG1 gene product which has been verified by DNA sequencing. Preparation of PCR reactions at different stages (e.g. addition of DNA and transfer of secondround products) was conducted in different rooms or in separate clean hoods. Due to unknown ratios of parasite to host DNA, all samples were tested 3 times at $1 \mu \mathrm{l}, 2 \mu \mathrm{l}$ and $1 \mu \mathrm{l} 1: 5$ dilution of sample DNA. Further validation of the reliability of the SAG1 PCR system has been described by us previously (Williams et al. 2005).

A nested PCR was used to detect the SAG3. This method has been modified from the method described by Grigg et al. (2001). Amplification was carried out in a final volume of $50 \mu \mathrm{l}$ containing $5 \mu \mathrm{l}$ of $10 \times$ HT PCR buffer (HT Biotechnologies) (100 mM Tris $\mathrm{HCl}$ (pH 9.0), $15 \mathrm{~mm} \mathrm{MgCl}_{2}, 500 \mathrm{~mm}$ $\mathrm{KCl}, 1 \%$ TritonX-100, $0 \cdot 1 \%$ (w/v) stabilizer), $0 \cdot 5 \mu \mathrm{l}$ of dNTP mix (100 mM), $2 \cdot 5 \mu \mathrm{l}$ of $(10 \mathrm{pM} / \mu \mathrm{l})$ forward primer $\mathrm{F}_{\mathrm{ext}}$ (5'CAACTCTCACCATTCCACCC3') and reverse primer $\mathrm{R}_{\text {ext }}$ (5'GCGCGTTGTTAGACAAGACA3') and $2 \cdot 5$ units Biotaq polymerase (Bioline). DNA-free water made the final volume to $50 \mu \mathrm{l}$. Due to unknown ratios of parasite to host DNA, all samples were tested 3 times at $1 \mu \mathrm{l}, 2 \mu \mathrm{l}$ and $1 \mu \mathrm{l}$ 1:5 dilution of sample DNA. Amplification was carried out using a Stratagene Robocycler as follows: an initial denaturation step of $5 \mathrm{~min}$ at $94{ }^{\circ} \mathrm{C}$, was followed by 35 cycles of PCR performed for $40 \mathrm{sec}$ at $94{ }^{\circ} \mathrm{C}, 40 \mathrm{sec}$ at $60^{\circ} \mathrm{C}$ and $60 \mathrm{sec}$ at $72^{\circ} \mathrm{C}$, with a final extension step of $10 \mathrm{~min}$ at $72^{\circ} \mathrm{C}$. Second-round PCR was carried out using the same reaction and cycling conditions as the first round with the exception of the primers which were $F_{\text {int }}$ (5'TCTTGTCGGGTGTTCACTCA3') and $\mathrm{R}_{\text {int }}$ (5'CACAAGGAGACCGAGAAGGA3'). A volume of $2 \mu \mathrm{l}$ of first-round product was added to act as a template. Amplification products $(10 \mu \mathrm{l})$ were visualized by agarose gel electrophoresis on a $2 \%$ agarose gel containing Gelred or ethidium bromide. Positive PCR reactions were further analysed by restriction enzyme digestion with each of the enzymes Nci1 and AlwN1, $8 \cdot 5 \mu \mathrm{l}$ of PCR product, $1 \mu \mathrm{l}$ of buffer $4(\mathrm{NEB})$ and $0 \cdot 5 \mu \mathrm{l}$ of enzyme. These were incubated at $37^{\circ} \mathrm{C}$ for a minimum of $4 \mathrm{~h}$. Products were visualized by gel electrophoresis on a $2 \cdot 5 \%$ agarose gel. $N$. caninum was detected by PCR as previously described (Hughes et al. 2006, 2008).

To confirm the sequence of PCR products, bands were excised from the agarose gel and cleaned using Geneclean $^{\circledR}$ before sequencing. Fragments of DNA sequence from SAG1 and SAG3 PCR amplifications were sent to Lark Technologies for bidirectional sequencing using the primers DS 38 and DS 39 (SAG1) and Fint and Rint (SAG3). N. caninum fragments were sequenced as previously described (Hughes et al. 2006, 2008). Sequence data were compared to previously published sequences using CLUSTAL W software available on the European Bioinformatics Institute website (www.ebi.ac.uk/ clustalw/).

Statistical analysis of data was carried out using Chi-Squared tests (Microsoft, EXCEL) or $2 \times 2$ contingency tables using Fishers Exact Test (Graphpad Software: http://www.graphpad.com/).

RESULTS

DNA was extracted from brain tissue taken from 206 A. sylvaticus and DNA integrity checked using PCR amplification of the Apodemus tubulin gene. SAG1 PCR was used to detect the presence of $T$. gondii DNA in the DNA extracted from brain tissue. Positive amplifications in 84 of the 206 samples demonstrated the prevalence of Toxoplasma infection to be $40 \cdot 78 \%$ (95\% CI: $34 \cdot 07 \%-47 \cdot 79 \%$ ) (Table 1$)$. To confirm that the correct DNA sequence was being amplified, DNA sequencing was carried out on a sample of PCR amplified product from a PCRpositive A. sylvaticus (Accession no. JF412000). There was a $100 \%$ match to published SAG1 sequences.

A subset of 111 mice $(42 \cdot 3 \%$ PCR positive), which had an associated comprehensive data set on parameters such as sex, weight and length, was used to investigate the relationship with Toxoplasma infection. To determine whether there was a relationship of infection with sex of the mice, 54 females and 57 males were found to have $23(42 \cdot 6 \%)$ and $24(42 \cdot 1 \%)$ PCR-positive mice respectively. No significant difference between $T$. gondii infection and sex was 
Table 2. Frequency of infection of Apodemus sylvaticus with Neospora caninum and Toxoplasma gondii

\begin{tabular}{lll}
\hline \hline & $\begin{array}{l}\text { N. caninum } \\
\text { positive }\end{array}$ & $\begin{array}{l}\text { N. caninum } \\
\text { negative }\end{array}$ \\
\hline $\begin{array}{c}\text { T. gondii } \\
\text { positive }\end{array}$ & 1 & 55 \\
$\begin{array}{c}\text { g. gondii } \\
\text { negative }\end{array}$ & 3 & 59 \\
Total & 4 & 114 \\
\hline \hline
\end{tabular}

found $\left(\chi^{2}=0.003\right.$, D.F. $\left.=1, P=0.957\right)$. As studies of Toxoplasma infection often show the presence of an age-dependent prevalence (i.e. higher prevalences are found in older cohorts), we tested this using these data. A total of 97 adults and 14 juveniles (those under $14 \mathrm{~g}$ ) were observed in this cohort of 111 of which $44(45 \cdot 3 \%)$ and $5(35 \cdot 7 \%)$ were PCR positive for Toxoplasma respectively. No significant difference between infection of adults and juveniles was found $\left(\chi^{2}=0.153\right.$, D.F. $\left.=1, P=0.6953\right)$ showing that no age-dependent prevalence increase was evident in this study.

For this study, 2 pregnant $A$. sylvaticus dams were collected. One was found to be PCR positive for $T$. gondii and SAG1 PCR detected parasite DNA in the brain tissue of 2 out of the 6 foetuses within this pregnant dam.

To gain an insight into the diversity of $T$. gondii strains within the $A$. sylvaticus population, as many as possible of the SAG1-positive animals were tested for RFLP with the SAG3-PCR method (Grigg et al. 2001) to determine strain type. Considerable difficulty was experienced in successfully amplifying sufficient quantities of the SAG3 product from the DNA of these tissue samples. SAG3 genotypes were determined for 22 of the PCR-positive mice. Of the 22 mice, 12 were of SAG3 Type I, 9 of Type II and 1 Type III.

PCR was used to investigate the prevalence of $N$. caninum in this population of $A$. sylvaticus. Of the A. sylvaticus there were 118 tested for $N$. caninum of which only 4 were positive, giving a prevalence of $3 \cdot 39 \%$ (95\% CI: $0 \cdot 12-6 \cdot 66 \%$ ) (Table 1$)$.

The question of co-infection between $T$. gondii and $N$. caninum has not been explored in $A$. sylvaticus to our knowledge although it has been investigated using a smaller sample of $M$. domesticus in a previous study (Hughes et al. 2006). Tables 2 and 3 , respectively, summarize the infection data for A. sylvaticus and the previously published M. domesticus data (Hughes et al. 2006) augmented with additional samples new to this study. Coinfection was observed in both populations but no significant association was found between $T$. gondii and $N$. caninum infection in either $A$. sylvaticus $(P=0.621)$ or $M$. domesticus $(P=0.622)$.
Table 3. Frequency of infection of Mus domesticus with Neospora caninum and Toxoplasma gondii

\begin{tabular}{lll}
\hline \hline & $\begin{array}{l}\text { N. caninum } \\
\text { positive }\end{array}$ & $\begin{array}{l}\text { N. caninum } \\
\text { negative }\end{array}$ \\
\hline $\begin{array}{c}\text { T. gondii } \\
\text { positive }\end{array}$ & 3 & 66 \\
$\begin{array}{c}T \text { gondii } \\
\text { negative }\end{array}$ & 1 & 60 \\
Total & 4 & 126 \\
\hline \hline
\end{tabular}

\section{DISCUSSION}

In this study a sympatric collection of $A$. sylvaticus was tested for the presence of $T$. gondii and $N$. caninum with prevalences of $40 \cdot 78 \%$ (95\%CI: $34 \cdot 1 \%-47 \cdot 8 \%)$ and $3 \cdot 39 \%$ (95\% CI: $0 \cdot 12 \%-6 \cdot 66 \%)$ respectively being measured. To our knowledge only one other PCR study has been conducted on the prevalence of $N$. caninum in A. sylvaticus-a prevalence of $1.8 \%$ was seen in a sample set of 55 animals collected in Italy (Ferroglio et al. 2007). This low prevalence was not significantly different from that seen with our larger collection $\left(\chi^{2}=0.412\right.$, D.F. $=1, P=0 \cdot 52)$. A comparison of $N$. caninum prevalences in this population of $A$. sylvaticus and an $M$. domesticus population collected from an urban area within Manchester, UK, showed a nonsignificantly different $\left(\chi^{2}=0.046\right.$, D.F. $\left.=1, P=0 \cdot 83\right)$ prevalence of $3 \cdot 08 \%(95 \% \mathrm{CI}: 0 \cdot 11 \%-6 \cdot 05 \%)$ using identical collection and detection systems. It is unclear how this parasite is transmitted in both of these rodent species. The $\mathrm{dog}$ is known to be the definitive host (McAllister et al. 1998) and vertical transmission is considered to be frequent in N. caninum (Williams et al. 2009). Co-infection was observed but no significant association was seen between infection with $N$. caninum and $T$. gondii in either the Apodemus or Mus hosts. This is consistent with PCR-based studies on other mammalian species (Hughes et al. 2006, 2008).

In the case of $T$. gondii, the cat clearly has a key role in the life cycle, raising the question as to how the prevalence of infection in rodents may differ in areas with high and low cat densities. The Apodemus in this study were collected from an area with an estimated cat density of less than $2 \cdot 5$ cats per $\mathrm{km}^{2}$ (based on recalculation of data from Hughes et al. 2008). In other, previously published studies (Marshall et al. 2004; Murphy et al. 2008) exactly the same techniques and approaches were used to measure the prevalence of $T$. gondii in an urban population of $M$. domesticus from an area of considerably higher cat density than the sampling site for A. sylvaticus. Details of the locations of cats within the study site were collated (Murphy et al. 2008) and a cat density of more than 500 cats per $\mathrm{km}^{2}$ was calculated (based on the data 
presented by Murphy et al. 2008). Two hundred $M$. domesticus collected from this urban population were found to have a prevalence of 59\% using SAG1 PCR of brain tissue (Marshall et al. 2004). Compared with the $40 \cdot 78 \%$ found in the A. sylvaticus samples, there was a higher prevalence $(59 \%)$ in the $M$. domesticus samples (Table 1) suggesting that the presence of cats clearly contributes to the prevalence of $T$. gondii. However, despite the 200 times higher density of cats in the $M$. domesticus sample site, only a further $19 \%(95 \% \mathrm{CI}: 11 \cdot 2 \%-26 \cdot 8 \%)$ increase in prevalence was seen. Clearly, therefore, high levels of infection in the Apodemus samples are being maintained in the relative absence of cats. We appreciate that other factors, such as the difference in species studied here (for example, in behaviour), may also influence the different prevalences although we found no evidence in the literature that might suggest differences in virulence towards Apodemus or Mus.

One possible transmission route that could maintain these relatively high prevalences is congenital transmission. Previous studies on the $M$. domesticus population showed the occurrence of high frequencies of congenital transmission (Marshall et al. 2004). In this study, 2 pregnant females (1 PCR positive) were found within the population of $A$. sylvaticus. Although only a very small sample size, the PCRpositive foetuses in one of them shows that congenital transmission is occurring in this $A$. sylvaticus population. This offers a possible explanation of how transmission might be occurring in the relative absence of cats. This hypothesis is further supported by the lack of an age prevalence effect when comparing the juvenile Apodemus with adult mice-a phenomenon which would be expected to be seen if the Apodemus acquired infection by ingestion of oocysts or carnivory.

Parasite multilocus genotyping might be one way of investigating whether frequent congenital transmission might be occurring. High degrees of similarity between genotypes might indicate the level of clonality expected to be associated with vertical transmission. In our studies, considerable difficulty was experienced in successfully amplifying sufficient quantities of the SAG3 product to directly genotype from these tissue samples, although all 3 main clonal genotypes were seen. The difficulty was probably due to a low parasite to host DNA ratio. The consequences of this difficulty were that we were unable to attempt multilocus genotyping which is now considered the norm for $T$. gondii genotyping. The range of SAG3 genotypes present in this Apodemus population may argue against congenital transmission occurring frequently.

The prevalence of $T$. gondii infection in both the Apodemus and Mus populations is high. This is in contrast to many serological studies that have reported relatively low Toxoplasma prevalence in mice (Franti et al. 1976; Jackson et al. 1986; Webster,
1994; Dubey et al. 1995; Hejlicek et al. 1997; Hejlicek and Literak, 1998). Few studies have been conducted to date on the woodmouse, $A$. sylvaticus. Prevalences of $T$. gondii of $14 \cdot 3 \%$ have been reported, using real-time PCR, in one study (Kijlstra et al. 2008) and seroprevalences of $1 \cdot 49 \%$ and $7 \cdot 4 \%$ found in A. agrarius in Korea (Jeon and Yong, 2000) and the Czech republic (Hejlicek and Literak, 1998). A study of prevalence of $T$. gondii in another rodent species, the Deer Mouse, (Peromyscus maniculatus) reported a prevalence rate of $26 \%$ (Dabritz et al. 2008). Interestingly, recent research has shown that high levels of congenital transmission can be detected following experimental infection of this latter species (Rejmanek et al. 2010).

The reasons behind the variability in prevalences of $T$. gondii in small rodents is unclear and especially the explanation for the high prevalences seen in our studies on UK species of Apodemus and Mus. Geographical variance, host species behaviour or methods of detection (e.g. serology vs PCR) could all be factors. There is a growing body of evidence that suggests that serological methods may not efficiently detect $T$. gondii infection in mice-especially if that infection is congenitally derived. This was first noticed by Beverley (1959), where serological detection was inefficient despite high mortality in congenitally infected mice. This has also been reported subsequently (Dubey et al. 1997; Owen and Trees, 1998; Araujo et al. 2010; Rejmanek et al. 2010).

The closely related parasite $N$. caninum is clearly capable of efficient vertical transmission and can be maintained in its hosts by endogenous transplacental transmission (Cole et al. 1995; Trees and Williams, 2005; Williams et al. 2009). Little is known about the mechanisms of endogenous transplacental transmission in $T$. gondii. One possibility is that the parasite is able to manipulate the host immune system during transplacental transmission such that it is either recognized as 'self' or not recognized at all. Further research in this area may be important if vertical transmission of $T$.gondii is relevant to natural populations of animals such as the woodmice in this study.

\section{ACKNOWLEDGEMENTS}

We would like to thank the University of Salford and the Libyan Embassy for funding. The University of Salford parasitology students, Manchester residents and the Manchester City Council for their help in the collection of the mice populations. Z.R.L.'s laboratory is supported by the grant from the National Basic Research Program of China (973 Program) (No. 2010CB530000).

\section{REFERENCES}

Araujo, J. B., da Silva, A. V., Rosa, R. C., Mattie, R. J., da Silva, R. C., Richini-Pereira, V. B. and Langoni, H. (2010). Isolation of multilocus genotyping of Toxoplasma gondii in seronegative rodents in Brazil. Veterinary Parasitology 174, 328-331. 
Beverley, J. K. A. (1959). Congenital transmission of toxoplasmosis through successive generation of mice. Nature, London 183, 1348-1349.

Cole, R. A., Lindsay, D. S., Blagburn, B. L. and Dubey, J. P. (1995). Vertical transmission of Neospora caninum in mice. Fournal of Parasitology 81, 730-732.

Dabritz, H. A., Miller, M. A., Gardner, I. A., Packham, A. E., Atwill, E. R. and Conrad, P.A. (2008). Risk factors for Toxoplasma gondii infection in wild rodents from central coastal California and a review of $T$. gondii prevalence in rodents. Fournal of Parasitology 94 675-683.

Dubey, J.P. (1995). Duration of immunity to shedding of Toxoplasma gondii oocysts by cats. Fournal of Parasitology 81, 410-415.

Dubey, J.P. (2009a). History of the discovery of the life cycle of Toxoplasma gondii. International fournal for Parasitology 39, 877882.

Dubey, J. P. (2009b). The evolution of the knowledge of cat and dog coccidia. Parasitology 136, 1469-1475.

Dubey, J. P. and Beattie, C. P. (1988). Toxoplasmosis of Animals and Man. CRC Press, Boca Raton, FL, USA.

Dubey, J.P., Hill, D. E., Jones, J. L., Hightower, A. W. Kirkland, E., Roberts, J. M., Marcet, P. L., Lehmann, T. Vianna, M. C. B., Miska, K., Sreekumar, C., Kwok, O.C.H., Shen, S. K. and Gamble, H. R. (2005). Prevalence of viable Toxoplasma gondii in beef, chicken and pork from retail meat stores in the United States: risk assessment to consumers. Fournal of Parasitology 91, 1082-1093.

Dubey, J. P. and Jones, J. L. (2008). Toxoplasma gondii infection in humans and animals in the United States. International Fournal for Parasitology 38, 1257-1278.

Dubey, J. P., Miller, N. L. and Frenkel, J. K. (1970). Toxoplasma gondii life cycle in cats. Fournal of the American Veterinary Medical Association 157, 1255-1255.

Dubey, J.P., Shen, S. K., Kwok, O.C. and Thulliez, P. (1997). Toxoplasmosis in rats (Rattus norvegicus): congenital transmission to first and second generation offspring and isolation Toxoplasma gondii from seronegative rats. Parasitology 115, 9-14.

Dubey, J. P., Weigel, R. M., Siegel, A. M., Thulliez, P., Kitron, U. D., Mitchell, M. A., Mannelli, A., Mateuspinillia, N. E., Shen, S. K., Kwok, O.C.H. and Todd, K.S. (1995). Sources and reservoirs of Toxoplasma gondii infection on 47 swine farms in Illinois. Fournal of Parasitology 81, 723-729.

Duncanson, P., Terry, R.S., Smith, J.E. and Hide, G. (2001) High levels of congenital transmission of Toxoplasma gondii in a commercial sheep flock. International fournal for Parasitology 31, 16991703.

Ferroglio, E., Pasino, M., Romano, A., Grande, D., Pregel, P. and Trisciuogjio, A. (2007). Evidence of Neospora caninum DNA in wild rodents. Veterinary Parasitology 148, 346-349.

Franti, C.E., Riemann, H.P., Behmeyer, D. E., Suther, D., Howarth, J. A. and Ruppanner, R. (1976). Prevalence of Toxoplasma gondii antibodies in wild and domestic animals in northern California. Fournal of the American Veterinary Medical Association. 169, 901-906.

Grigg, M. E., Ganatra, J., Boothroyd, J. C. and Margolis, T. P. (2001). Unusual abundance of atypical strains associated with human ocular toxoplasmosis. Fournal of Infectious Diseases 184, 633-639.

Hejlicek, K. and Literak, I. (1998). Long-term study of Toxoplasma gondii prevalence in small mammals (Insectivora and Rodentia). Folia Zoologica 47, 93-101.

Hejlicek, K., Literak, I. and Nezval, J. (1997). Toxoplasmosis in wild mammals from the Czech Republic. Fournal of Wildlife Diseases 33, $480-485$.

Herrmann, D. C., Pantchev, N., Vrhovec, M. G., Barutzki, D., Wilking, H., Fröhlich, A., Lüder, C. G., Conraths, F. J. and Schares, G. (2010). Atypical Toxoplasma gondii genotypes identified in oocysts shed by cats in Germany. International fournal for Parasitology $\mathbf{4 0}$, 285-292.

Hide, G., Gerwash, O., Morley, E. K., Williams, R.H., Hughes, J.M., Thomasson, D., Elmahaishi, M.S. Elmahaishi, K. H., Terry, R.S. and Smith, J. E. (2007). Does vertical transmission contribute to the prevalence of toxoplasmosis? Parassitologia 49, 223-226.

Hide, G., Morley, E. K., Hughes, J. M., Gerwash, O. Elmahaishi, M. S., Elmahaishi, K. H., Thomasson, D., Wright, E. A., Williams, R. H., Murphy, R. G. and Smith, J. E. (2009). Evidence for high levels of vertical transmission in Toxoplasma gondii. Parasitology 136, $1877-1885$.
Higgs, S. and Nowell, F. (2000). Population biology of Eimeria (protozoa: Apicomplexa) in Apodemus sylvaticus: a capture study. Parasitology 120, 355-363.

Hughes, J. M., Thomasson, D., Craig, P.S., Georgin, S., Pickles, A. and Hide, G. (2008). Neospora caninum: detection in wild rabbits and investigation of co-infection with Toxoplasma gondii by PCR analysis. Experimental Parasitology 120, 255-260.

Hughes, J. M., Williams, R. H., Morley, E. K., Cook, D. A. N., Terry, R.S., Murphy, R. G., Smith, J.E. and Hide, G. (2006). The prevalence of Neospora caninum and co-infection with Toxoplasma gondii by PCR analysis in naturally occurring mammal populations. Parasitology $\mathbf{1 3 2}$ 29-36.

Innes, E. A., Bartley, P. M., Buxton, D. and Katzer, F. (2009). Ovine toxoplasmosis. Parasitology 136, 1887-1894.

Jackson, M. H., Hutchison, W. M. and Siim, J.C. (1986). Toxoplasmosis in a wild rodent population of Central Scotland and a possible explanation of the mode of transmission. Fournal of Zoology 209, 549-557.

Jacobs, L. (1964). The occurrence of Toxoplasma infection in the absence of demonstrable antibodies. In First International Congress of Parasitology, Vol. 1 (ed. Caorradetti, A.), pp. 176-177. Pergamon Press. Rome, Italy.

Jeon, S. H. and Yong, T. S. (2000). Serological observation of Toxoplasma gondii prevalence in Apodemus agrarius, a dominant species of field rodents in Korea. Yonsei Medical fournal 41, 491-496.

Kijlstra, A., Meerburg, B., Cornelissen, J., De Craeye, S., Vereijken, P. and Jongert, E. (2008). The role of rodents and shrews in the transmission of Toxoplasma gondii to pigs. Veterinary Parasitology 156, 183-190.

McAllister, M. M., Dubey, J.P., Lindsay, D. S., Jolley, W. R., Wills, R. A. and McGuire, A.M. (1998). Dogs are the definitive hosts of Neospora caninum. International Fournal for Parasitology 28, 1473-1478.

Marshall, P. A., Hughes, J.M., Williams, R. H., Smith, J.E., Murphy, R. G. and Hide, G. (2004). Detection of high levels of congenital transmission of Toxoplasma gondii in natural urban populations of Mus domesticus. Parasitology 128, 39-42.

Morley, E. K., Williams, R.H., Hughes, J. M., Terry, R.S., Duncanson, P., Smith, J.E. and Hide, G. (2005). Significant familial differences in the frequency of abortion and Toxoplasma gondii infection within a flock of Charollais sheep. Parasitology 131, 181-185.

Morley, E. K., Williams, R.H., Hughes, J.M., Thomasson, D., Terry, R. S., Duncanson, P., Smith, J. E. and Hide, G. (2008). Evidence that primary infection of Charollais sheep with Toxoplasma gondii may not prevent foetal infection and abortion in subsequent lambings. Parasitology 135, 169-173.

Murphy, R. G., Williams, R. H., Hughes, J. M., Hide, G., Ford, N. J. and Oldbury, D. J. (2008). The urban house mouse (Mus domesticus) as a reservoir of infection for the human parasite Toxoplasma gondii: an unrecognised public health issue? International Fournal of Environmental Health Research 18, 177-185.

Owen, M. R. and Trees, A. J. (1998). Vertical transmission of Toxoplasma gondii from chronically infected house (Mus musculus) and field (Apodemus sylvaticus) mice determined by polymerase chain reaction. Parasitology $\mathbf{1 1 6}$, 299-304.

Rejmanek, D., Vanwormer, E., Mazet, J. A. K., Packham, A. E., Aguilar, B. and Conrad, P.A. (2010). Congenital transmission of Toxoplasma gondii in deer mice (Peromyscus maniculatus) after oral oocyst infection. Fournal of Parasitology 96, 516-520.

Schares, G., Vrhovec, M. G., Pantchev, N., Herrmann, D. C. and Conraths, F. J. (2008). Occurrence of Toxoplasma gondii and Hammondia hammondi oocysts in the faeces of cats from Germany and other European countries. Veterinary Parasitology 152, 34-45.

Smith, D. D. and Frenkel, J.K. (1995). Prevalence of antibodies to Toxoplasma gondii in wild mammals of Missouri and East Central Kansas - biologic and ecologic considerations of transmission. Fournal of Wildlife Diseases 31, 15-21.

Su, C., Evans, D., Cole, R.H., Kissinger, J. C., Ajioka, J.W. and Sibley, L. D. (2003). Recent expansion of Toxoplasma through enhanced oral transmission. Science 299, 414-416.

Tenter, A. M., Heckeroth, A. R. and Weiss, L. M. (2000). Toxoplasma gondii: from animals to humans. International Fournal for Parasitology 30, 1217-1258.

Terry, R. S., Smith, J. E., Duncanson, P. and Hide, G. (2001). MGEPCR: a novel approach to the analysis of Toxoplasma gondii strain differentiation using mobile genetic elements. International fournal for Parasitology 31, 155-161. 
Trees, A. J. and Williams, D. J. L. (2005). Endogenous and exogenous transplacental infection in Neospora caninum and Toxoplasma gondii. Trends in Parasitology 21, 558-561.

Webster, J. P. (1994). Prevalence and transmission of Toxoplasma gondii in wild brownrats, Rattus norvegicus. Parasitology 108, 407-411.

Williams, D. J. L., Hartley, C. S., Bjorkman, C. and Trees, A. J. (2009). Endogenous and exogenous transplacental transmission of Neospora caninum-how the route of transmission impacts on epidemiology and control of disease. Parasitology 136, 1895-1900.
Williams, R.H., Morley, E. K., Hughes, J.M., Duncanson, P., Terry, R. S., Smith, J. E. and Hide, G. (2005). High levels of congenital transmission of Toxoplasma gondii in longitudinal and cross-sectional studies on sheep farms provides evidence of vertical transmission in ovine hosts. Parasitology 130, 301-307.

Zhang, S. Y., Jiang, S. F., He, Y. Y., Pan, C. E., Zhu, M. and Wei, M. X. (2004). Serologic prevalence of Toxoplasma gondii in field mice, Microtus fortis, from Yuanjiang, Hunan province, People's Republic of China. Fournal of Parasitology 90, 437-438. 